\title{
Correction: Taste loss with obesity in mice and men
}

\section{Andrew Kaufman · Jennie Kim · Corinna Noel $\cdot$ Robin Dando}

Published online: 21 August 2020

C Springer Nature Limited 2020

Correction to: International Journal of Obesity https://doi.org/10.1038/s41366-019-0429-6

A

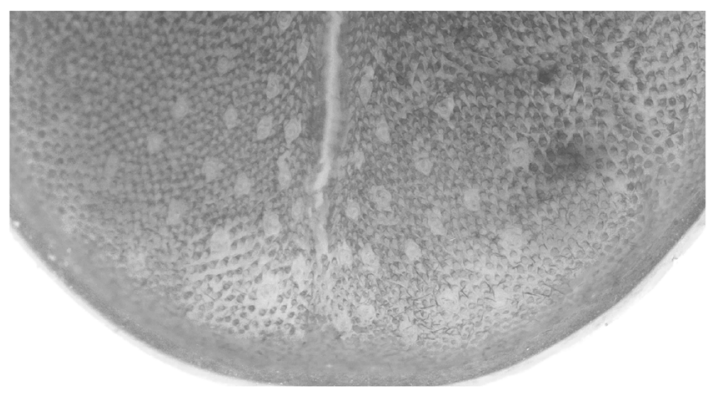

C

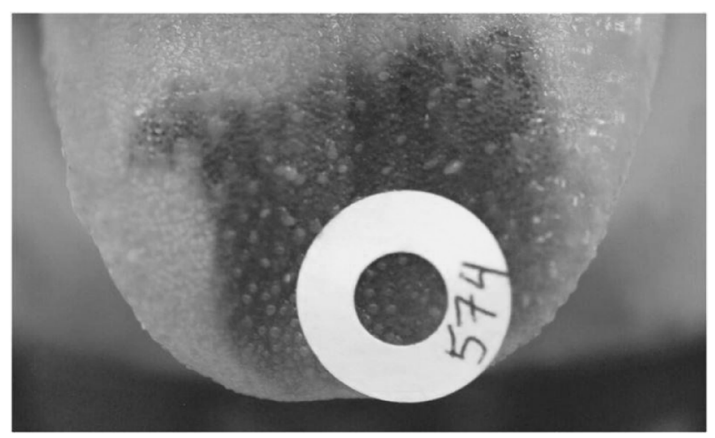

Figure 2 has been edited to correct an improperly labeled axis. Please see the correct version below.

\section{B}

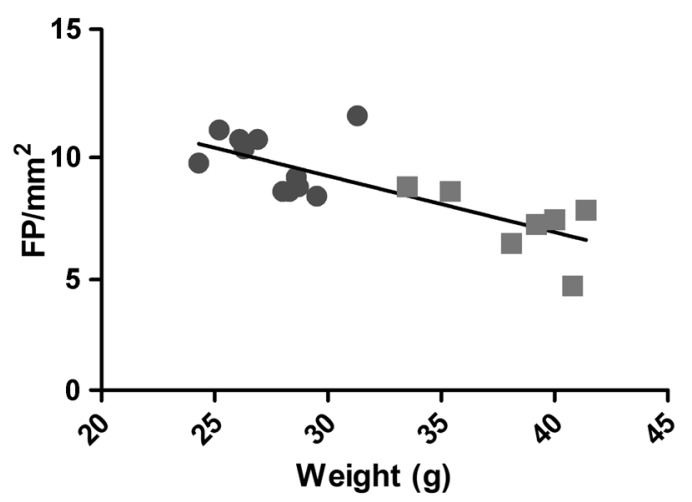

D

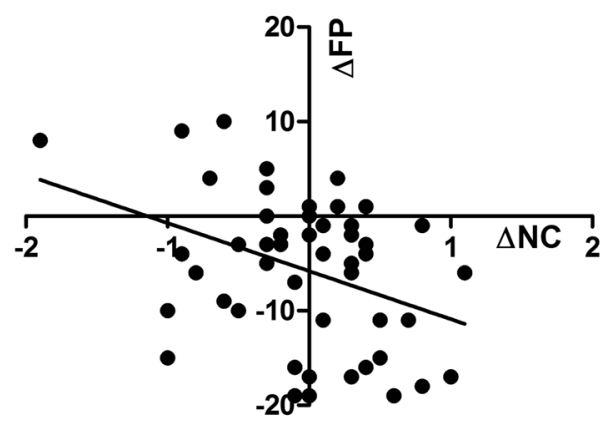

Fig. 2 